outside and at many stages during the developmental period from very small ovary primordia to mature fruit.

In each tissue growth takes place at first chiefly by cell multiplication, though cell size slowly increases also. After a specific cell size is reached, division ceases, and all further growth of this tissue is by cell expansion.

The innermost tissues, as compared with the successively outer ones, show (a) more rapid increase in cell size during the period of cell division, $(b)$ earlier cessation of division, and (c) greater cell size at the time when division ceases.

In Cucurbita Pepo, large-fruited races as compared with small-fruited ones typically show (a) no difference in cell size during early development; $(b)$ a more extended period of cell division, due to less rapid increase in cell size, greater cell size at the time of last division, and a greater interval between the cessation of division in successive tissues; and (c) greater cell expansion after cell division ceases.

Differences in fruit size are therefore usually due to differences in both cell number and cell size, though either factor may alone be responsible in certain cases.

Specific differences in development between $\mathrm{Cu}$ curbita and the three other genera are described.

Possible factors responsible for the differences in cell division and in cell expansion between the various tissues and in the various races are discussed.

The problem of the size relation of cell to organ is part of the more general problem of the factors determining growth and differentiation. The first step in the solution of this problem is a thorough descriptive analysis in quantitative terms.

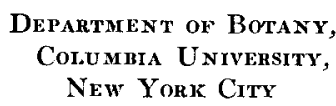

LITERATURE CITED

Amelung, E. 1893. Über mittlere Zellengrössen. Flora $77: 176-207$.

Huxiey, J., ANd G. Teissinr. 1936. Terminology of relative growth. Nature 137: 780 .

Gustafson, F. G. 1939. Auxin distribution in fruits. Amer. Jour. Bot. 26: 189-194.

Houghtaling, Helen B. 1935. A developmental analysis of size and shape in tomato fruits. Bull. Torrey Bot. Club 62: 243-252.
MacArthur, J. W., axd L. Butler. 1938. Size inheritance and geometric growth processes in the tomato fruit. Genetics 23: 253-268.

Sacis, J. 1893. ¿̈ber einige Beziehungen der specifischen Grösse der Pflanzen zu ihrer Organisation. Flora $77: 49-81$.

Srin moтr, E. W. 1930. The morphogenetic relationships between cell and organ in the petiole of $A$ cer. Bull. Torrey Bot. Club 57: 1-20.

\title{
AUXIN DISTRIBUTION IN FRUITS AND ITS SIGNIFICANCE IN FRUIT DEVELOPMEN'T ${ }^{1}$
}

\author{
Felix G. Gustafson
}

Growth substances or auxins, as they will be called in this paper (Went and Thimann, 1937), are now generally considered to be factors in vegetative growth of plants. Recent investigations on artificial parthenocarpy produced by chemicals (Gustafson, 1936; Hagemann, 1937; Gardner and Marth, 1937) have shown that auxin under artificial conditions can also cause fruit development without fertilization. This coupled with the fact that auxin has been shown to be widely distributed in the vegetative parts of plants leads one to assume that auxin is also concerned with normal fruit growth. Gustafson (1939) has proposed the theory that a high auxin content in the ovary in the flower bud stage is responsible for natural parthenocarpy, which is found

${ }^{1}$ Received for publication December 15, 1938.

Paper from the Department of Botany of the University of Michigan, No. 682.

The writer wishes to express his thanks and appreciation to F. W. Went, E. G. Anderson, J. Van Overbeek, and William S. Stewart, of the California Institute of Technology, and to William Hertrich of the Huntington Gardens, San Marino, California, for various aids extended during the course of this investigation and to the Directors of the Horace H. Rackham Trust Fund of the University of Michigan for financial aid. in many plants. In this paper it was shown that the auxin content is actually much higher in the ovaries of those plants that produce fruits parthenocarpically than in similar varieties requiring fertilization for fruit production.

Before it is possible to proceed very far with this matter, it is first necessary to investigate the auxin distribution in fruits. In 1936 Dollfus published some experiments which tended to show that auxin is produced in the developing seeds. He used the diffusion method. In these experiments he found that a substance diffused from the ovules into the agar which caused Avena coleoptiles to curve, but no such substance diffused out of the outer part of the ovary. Meyer (1936) has also found auxin in fruits. He extracted the auxin with alcohol in a reflux condenser for two hours and mixed the extract from 10 grams of fresh material with 1 gram of lanolin, which was applied to one side of intact. Avena coleoptiles. While this method is perhaps not so good as the method in which agar containing the auxin is applied to decapitated etiolated Avena. coleoptiles, nevertheless it is fairly accurate. In these experiments Meyer used a number of species 
of plants, and in the fruits of all these species he was able to demonstrate the presence of auxin. He did not do much with the distribution within the fruits, but in the few determinations he made, seed material gave a greater Avena coleoptile curvature than the other parts of the fruit.

The present work was undertaken to investigate further the auxin distribution in fruits. Fruits from many plants, in different stages of development and during different seasons, were used.

Procedure.- The work here reported was done at the William G. Kerckhoff Laboratories at the California Institute of Technology. Part of the experimental material was grown especially either in the greenhouse or in the field, while some of it, as the Yucca Whipplei, Agave Brundigii, Pittosporum undulatum, and Clivia sp., was obtained from the Huntington Gardens at San Marino. The auxin content and distribution was determined by the Avena method, the technique of which has been discussed in detail by Went and Thimann (1937).

Auxin was extracted with freshly distilled ether according to Van Overbeek's (1938) modification of other methods. The dried residue was thoroughly mixed with a known amount (usually .4 to $.8 \mathrm{cc}$.) of 1.5 per cent agar and after standing 90 minutes was poured into a nickel plated brass mold $1.5 \times 8.0 \times$ $10.5 \mathrm{~mm}$. in size. After the agar had been cut level with the surface of the mold, the large block was cut into 12 equal pieces. The material was now ready for the test. Great care was taken to have freshly prepared extracts. Usually the extract was prepared the same day that it was used, but if the extract could not be used the same day that it was made, it was always stored in a refrigerator in dried condition. Fleshy material was repeatedly extracted until the Avena test plants showed no curvatures when treated with the agar-extract. In some experiments such material as tomato and squash was first frozen with liquid air then ground in a mortar and the ether added. The extraction was always carried out in the dark and usually, though not always, at a low temperature.

Control experiments in which Avena plants were treated with a known concentration of indole acetic acid (usually 21.5 gamma per liter) were run with every experiment. (This concentration ordinarily gave a curvature of about $10-12^{\circ}$.) By this means the sensitivity of the test plants was determined for each experiment, which was very important, because there was considerable variation day by day, and the auxin concentration in a plant can be calculated in terms of indole acetic acid (see Van Overbeek) rather than in terms of some of the many units which have been employed by different investigators. This procedure has the advantage that the activity of the growth substance or substances is recorded in terms of a known and easily obtainable substance, indole acetic acid. One does not know what the substance is nor is its concentration known, but it is known that its activity on a decapitated Avena coleoptile is equal to a known concentration of indole acetic acid.
A few experiments were performed in which the plant material was placed on the agar blocks as in Went's original experiments. In most instances such blocks when placed on Avena coleoptiles caused no curvatures. It had been hoped that this method could be used, but as so few plants gave any results, it was abandoned for the extraction method. This brings up a question which is in the minds of many-namely: Is extracted auxin the same as that which diffuses into the agar block, and if so, is the concentration in the plants that give negative results so low that only by using a large quantity of material can a test be obtained; or is the auxin which is obtained by extraction released from a combined form, with low diffusibility, by the extraction treatment? Those experiments in which, by daily extraction, active material continued to be obtained for a period of 10 days certainly suggest an affirmative answer to the latter alternative.

In these experiments the fruits were separated into an interior and exterior part, or, as in the tomato and summer squash, further subdivisions were made. When a fruit was divided into only two parts, the interior part included the central axis, the placentae, the ovules and all the cells in between and immediately surrounding the ovules, and the exterior part usually included only the ovary wall, as in the peppers, tomatoes, beans, and Yucca. In the second experiment with peppers, listed in table 1 , the beans and Yucca, only the ovules and seeds were included in the interior part. The extraction method varied considerably in these experiments. All material was cut into rather small pieces to begin with, but in some experiments these pieces were frozen with liquid air, and while they were in the frozen condition, attempts at maceration were made. These differences in treatment of the material should in no way infuence the results, as all material experimented with at any one time was always treated in the same way, and extractions were continued until no further reaction was obtained with the Avena coleoptiles.

The investigation was divided into two parts. Part one dealt with the auxin distribution in nonparthenocarpic fruits, and the second part with a comparison of auxin concentration in artificial parthenocarpic and non-parthenocarpic fruits. In the second part the same plants were used, and the extractions were of course made at the same time.

RESULTS AND Discussion.-Distribution of auxin teithin non-parthenocarpic fruits.-In determining the auxin distribution within fruits, a number of different plants were used, and the experiments extended over a period of five months from March to August. The differences in auxin contents that have been noted in different experiments with the same species of plants are probably partly due to seasonal differences and partly to difference in the vigor of the plants. The tomatoes in table 1 , the first experiment with peppers in table 1 , and all the peppers in table 5 were grown in the greenhouse during the winter or early summer, and the plants 
TABIE 1. Auxin distribution within fruits. The interior includes only ovules or seeds in Yucca, beans, and the second experiment with peppers; otherwise it includes the central axis, the placentae, ovules, and all cells in between or closely associated with them. Figures denote auxin concentration in terms of indole acetic acid equivalents in gammas per kilogram green weight, except in the diffusion experiment with Pittosporum. T'he second experiment with peppers, the experiments with cucumbers, crookneck summer squashes, and beans zeere made during the summer, and the others during the zointer or spring.

\begin{tabular}{|c|c|c|c|c|}
\hline Plant & Interior & $\begin{array}{l}\text { Weight } \\
\text { of mate- } \\
\text { rial, in } \\
\text { grams }\end{array}$ & Outside & $\begin{array}{l}\text { Weight } \\
\text { of mate- } \\
\text { rial, in } \\
\text { grams }\end{array}$ \\
\hline $\begin{array}{c}\text { Pepper (first experi- } \\
\text { ment) }\end{array}$ & 0.16 & 31.7 & 0.07 & 156.2 \\
\hline $\begin{array}{l}\text { Pepper (second ex- } \\
\text { periment }) \ldots \ldots\end{array}$ & 61.90 & 3.95 & 9.29 & $6+.0$ \\
\hline Tomato $\ldots \ldots \ldots$ & 0.06 & 91.40 & 0.02 & 276.60 \\
\hline Agave Brundigii ... & 0.27 & 31.0 & 0.06 & 85.0 \\
\hline $\begin{array}{l}\text { Cucumber } \ldots \ldots \ldots \\
\text { Crookneck summer } \\
\text { squash }\end{array}$ & 5.06 & 25.7 & 1.99 & 81.0 \\
\hline Buds $\ldots \ldots \ldots$ & 14.09 & 7.32 & 7.52 & 12.66 \\
\hline Flowers & 7.30 & 16.42 & 1.21 & 21.50 \\
\hline $\begin{array}{c}\text { Young fruits ..... } \\
\text { Kentucky wonder } \\
\text { bean }\end{array}$ & 0.58 & 36.55 & 0.00 & 124.15 \\
\hline Pods $7-10 \mathrm{~cm} . .$. & 108.80 & 2.19 & 3.24 & 64.1 \\
\hline Pods $12-14 \mathrm{~cm} . .$. & 90.89 & 8.55 & 1.41 & 152.5 \\
\hline $\begin{array}{l}\text { Pods about } 19 \mathrm{~cm} . \\
\text { Yucca Whipplei }\end{array}$ & 7.00 & 33.66 & 0.46 & 73.1 \\
\hline Fruits $1.8 \times 2.7 \mathrm{~cm}$. & 0.34 & 19.55 & 0.19 & 42.05 \\
\hline Fruits $2.3 \times 3.4 \mathrm{~cm}$. & 0.67 & 22.28 & 0.13 & 38.04 \\
\hline $\begin{array}{l}\text { Fruits } 2.5 \times 3.5 \mathrm{~cm} \text {. } \\
\text { Pittosporum undula- } \\
\text { tum (diffusion) } 24\end{array}$ & 0.23 & 26.74 & 0.12 & 40.58 \\
\hline $\begin{array}{l}\text { Avena coleoptiles } \\
\text { used } \ldots \ldots \ldots \ldots\end{array}$ & $4.6^{\circ}$ & & 0.00 & \\
\hline
\end{tabular}

were not particularly vigorous, while the second experiment with peppers employed fruits grown in the field, where the plants were much more vigorous. The fruits were also larger. Even though there was considerable difference between different lots of fruits, the relative concentrations within the fruits were much the same in all experiments with the same fruit. The auxin concentration was much lower in the winter and spring than in the summer.
From the information gained in these experiments Yucca in which only seeds or ovules were used. In it seems as if the seeds or developing seeds must be centers of auxin production. This is particularly indicated by the experiments with peppers, beans, and the other fruits other cells adjoining the seeds were used, and the results are not so positive for them. To clear up this point, crookneck summer squash and tomatoes were used in several experiments in which the seeds were separated from the rest of the fruit, which was further subdivided.

TAнц 2. Auxin distribution in fruits of tomato and crookneck summer squash. Auxin concentration is denoted in terms of indole acetic acid equivalent, and the figures denote gammas per kilogram of fresh material. These experiments were made during the summer.

\begin{tabular}{|c|c|c|c|c|}
\hline $\begin{array}{l}\text { Plant and condi- } \\
\text { tion of fruit }\end{array}$ & $\begin{array}{l}\text { Seeds } \\
\text { or ovules }\end{array}$ & $\begin{array}{l}\text { Tissue } \\
\text { around } \\
\text { ovules }\end{array}$ & $\begin{array}{l}\text { Ovary } \\
\text { wall }\end{array}$ & $\begin{array}{c}\text { Neck of } \\
\text { squash } \\
\text { without } \\
\text { seeds }\end{array}$ \\
\hline $\begin{array}{c}\text { Squash, yellow, } \\
\text { cm. long, w } \\
779.2 \mathrm{~g} \ldots \ldots\end{array}$ & $\quad 1.31$ & 3.38 & 0.48 & 0.12 \\
\hline $\begin{array}{l}\text { Tomato, green, } 4- \\
\text { cm. } \quad \ldots \ldots \ldots \ldots\end{array}$ & 10.60 & 2.15 & 0.36 & $\ldots$ \\
\hline
\end{tabular}

In two experiments tomato fruits were separated into five parts and these parts extracted separately. Included in one of these experiments were parthenocarpic fruits produced by phenylacetic acid. Phenylacetic acid is known to give practically no Avena test, and therefore fruits were produced by its stimulation to determine whether these parthenocarpic fruits make or at least contain auxin. Table 3 gives the result of these experiments.

These experiments show that the ovules or young seeds are high in auxin content and that the other parts of the fruits contain much less auxin. Whether this auxin is produced in the ovules or diffuses into them from the leaves, we have no way of knowing from these experiments. Nevertheless, the results as a whole indicate that growth (however initiated) sets up a concentration gradient with the highest concentration in the ovules, when present, otherwise in the central axis and partition region and with a low concentration in the ovary wall.

'Tавц. 3. Auxin distribution in tomato fruits, produced by pollination and parthenoearpically by by phenylacetic acid. The fruits zere green and between 4.5 and $6.0 \mathrm{~cm}$. in diameter. Auxin concentration is denoted in terms of indole acetic acid equivalent, and the figures indicate gammas per kilogram of fresh material. These experiments were made during the summer.

\begin{tabular}{|c|c|c|c|c|c|}
\hline 'Type of fruit & Seeds & $\begin{array}{c}\text { Jelly } \\
\text { around seeds } \\
\text { or ovules }\end{array}$ & Placentae & $\begin{array}{c}\text { Central } \\
\text { axis and } \\
\text { partitions }\end{array}$ & Pericarp \\
\hline Normal (Exp. 57) .. & 15.33 & 6.57 & 2.44 & 2.27 & 1.27 \\
\hline 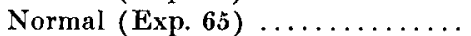 & 30.03 & 0.45 & 2.47 & 2.69 & 0.63 \\
\hline Parthenocarpic (Exp. 65) ...... & $\ldots$ & 1.25 & 0.49 & 6.42 & 0.81 \\
\hline
\end{tabular}


Comparison of auxin content in parthenocarpic and normal fruits.-In the preceding section it has been shown that the ovules or seeds of fruits have a high auxin content. In order to answer some of the questions which have been raised concerning the growth of fruits, it is necessary to know whether or not there is auxin production or accumulation in fruits when no seeds are produced.

It is a well-known fact that in certain interspecific crosses or even in intergeneric crosses, the ovary may develop into a fruit without any seeds. According to Yasuda (1935) the pollen tubes bring into the ovary something which stimulates growth. This is undoubtedly auxin (Gustafson, 1937). The auxin brought into the ovary is certainly not sufficient to cause continued growth, and the query has been made as to where this additional growth substance

TABLE 4. Comparison betreeen auxin concentration in normal and parthenocarpic tomato fruits. Auxin concentration is denoted in terms of indole acetic acid equivalent, and the figures indicate gammas per kilogram fresh weight.

\begin{tabular}{|c|c|c|c|c|}
\hline \multirow[b]{2}{*}{ Condition of fruit } & \multicolumn{2}{|c|}{ Pollinated } & \multicolumn{2}{|c|}{ Parthenocarpic } \\
\hline & Pericarp & Interior & Pericarp & Interior \\
\hline \multicolumn{5}{|l|}{ Green, $3.0 \times$} \\
\hline $4.0 \mathrm{~cm} . \operatorname{diam}$. & 4.00 & 27.03 & 0.40 & 0.72 \\
\hline \multicolumn{5}{|l|}{ Green, $4.6 \times$} \\
\hline $6.5 \mathrm{~cm}$ & 2.57 & 7.53 & 0.73 & 2.06 \\
\hline
\end{tabular}

comes from. Another variation of the above question has been concerned with the growth of normal parthenocarpic fruits as oranges, lemons, and grapes. Where does the auxin come from that causes them to grow? There is probably no pollination and no development of seeds. In artificial parthenocarpy produced by chemicals, interest has centered around the continuation or non-continuation of growth in a fruit after the initial stimulation. Gustafson (1937, $1938 \mathrm{a}, 1938 \mathrm{~b}$ ) has reported a number of instances in which the initial growth stopped very soon, whereas at other times a fruit continued to grow until half size and then stopped; in still other fruits growth continued until maturity. What is the cause of this difference in behavior? Is the auxin supplied to the ovary in the form of paste or spray causing all of the growth during the enlargement of the fruit, or does the developing fruit itself supply a part? Gardner and Marth (1937) found that four sprayings produced a larger percentage of setting than a single spraying. It is not clear whether this means that a greater percentage of flowers on a branch produced fruits or whether a larger number of treated flowers produced fruits. From the sentence following their statement that several treatments are more efficacious than a single one, it seems that they have reference to the whole branch. "In the practical use of these compounds in producing fruit on holly, successive spraying would be necessary in that the blossoms are not all open at one time." Several injections of auxin into ovaries and fruits of tobacco produced no more growth than a single injection, according to Gustafson (1938a). If Gardner and Marth's statement has reference to a cluster of holly flowers as a whole, it would seem that the added auxin merely initiates the growth and that the ovary either produces or obtains from the leaves enough for its continued growth and that if this source is not sufficient for the needs, the fruit stops growing.

To obtain information on this point, tomato fruits were produced parthenocarpically by means of phenylacetic acid. Phenylacetic acid, as mentioned before, has only a very slight influence on the Avena test. The auxin determination was made in the usual way. Table 3 shows one of these experiments, and in table 4 are found two more determinations on such fruits.

Parthenocarpic fruits produced by naphthalene acetic and indole butyric acids were also used, and table 5 gives the results for peppers. These fruits were grown in the greenhouse, during the spring and early summer.

According to Went and Thimann (1937), indole butyric and naphthalene acetic acids produce slight curvatures in Avena coleoptiles so that we have no information about the naturally occurring auxin in these experiments, but they definitely demonstrate that there are growth promoting substances in the growing fruits to which the Avena is sensitive; whether these are the substances added at the time of flowering or natural growth hormones, we do not know. The concentration of this active substance is lower than in normal fruits, however.

In the experiments with fruits produced by phenylacetic acid there is no doubt that parthenocarpic tomatoes contain naturally occurring auxin. If auxin occurs in tomatoes, one would expect it to be present also in other fruits. Whether this auxin is produced in the fruit or conducted into it from other

Tarie 5. Comparison between auxin content in normal and parthenocarpic peppers. Amount of material used is denoted in grams inside the brackets. Auxin concentration is denoted in terms of indole acetic acid equivalents, and the figures indicate gammas per kilogram of fresh material.

\begin{tabular}{cccccc}
\hline \hline \multicolumn{2}{c}{ Normal fruits } & & \multicolumn{2}{c}{ Parthenocarpic whole fruit } \\
\cline { 1 - 1 } Seeds and placentae & Pericarp & & Naphthalene ac. & Indole butyric \\
\hline $0.16(31.7)$ & $0.07(156.2)$ & & $0.07(114.0)$ & \\
$0.53(15.0) \quad 0.80(16.6)$ & $0.1(100.0)$ & & $0.25(49.5)$ & $0.18(51.0)$
\end{tabular}


sources, we do not know, and it need be of no concern. That it is there is the main point.

It then seems very likely that in some fruits there is a quantity of auxin sufficient for the needs of continued growth, after growth has once been initiated, even though no seeds are produced, while in others the amount is too low for the needs of a continued growth, and development ceases after some time. In varieties where mature parthenocarpic fruits have never been obtained, it is likely that the naturally occurring auxin content is always too low to sustain growth after the artificial supply has been depleted, and the only way such fruits can be made to grow and mature is by continuously supplying them somehow with auxin as do the seeds in nonparthenocarpic fruits, but we have not yet discovered a method of successfully doing this.

In normal fruits in which pollination and fertilization are necessary we can consider it a reasonable hypothesis that the initiation of growth of the ovary into a fruit results from the auxin bronght into it by the pollen tubes. If this is true, then one might expect that right after pollination the auxin content should be higher than just before. Meyer reports that just after fertilization, which might have reference to pollination, the auxin concentration in the female flowers of Cucurbita Pepo, Cucumis sativus, and Helianthus annuus was much higher than just before fertilization, and he also makes the general statement that there is less growth hormone in female flowers before fertilization than afterwards. In the present investigation there is little if any evidence that there is more auxin after pollination than before. In fact, it would be very difficult to get such information when much material is needed for extraction. Even if it could not actually be shown that the auxin content was higher after pollination, that is no serious criticism of the hypothesis, because even a little auxin added in the right place, as the ovules, would be sufficient to cause them to grow and set up auxin centers from which auxin might diffuse into the ovary. In a preceding paper (Gustafson, 1939), it was shown that in two-week-old Paper rind and Valencia seeded oranges the auxin content had increased very much over that in the flower stage. After the embryo has commenced growing, auxin in considerable quantity is present in the seed. This auxin undoubtedly diffuses into other parts of the ovary, where growth takes place. Even if seeds are not produced, there is auxin present in the ovary.
Some may hesitate to accept the idea of auxin playing such an important rôle in the growth of fruits. Let these consider that fruits have artificially been started and caused to develop by the addition of auxin. If auxin is able to do this when added from the outside, is there any reason why it should not play an important part under normal conditions? Furthermore, let it also be remembered that the mere pollination without fertilization does sometimes cause fruits to develop, and auxin has been extracted from pollen (Laibach, 1932; Thimann, 1934), and Gustafson (1937) extracted a substance which, when placed on the pistil of a flower, caused it to develop into a fruit. All these experiments show that there is auxin in the pollen and that it may cause growth of fruits.

In spite of these statements it is to be understood that auxin is not considered to be the only factor involved in fruit growth. In a recent publication Went (1938) considers that auxin acts in such a way as to cause other substances which he calls calines to move to the part of the plant where growth takes place. Thus he considers that auxin causes the caulocaline to move to the apex of a stem where it functions in the growth of the stem. The auxin may then be thought of as a master reagent causing other substances to produce growth of one sort or another. If this idea is applied to the growth of fruits, it becomes obvious that auxin causes some other substance or substances to move into the ovary of a flower and there cause growth to take place. It is not necessary at the present time to have a name for such a hypothetical substance, but by analogy it would be carpocaline, if different from other formative substances.

\section{SUMMARY}

The auxin content of ovules and developing seeds is much greater than that of other parts of fruits, and it is considered possible, even though not yet proved, that they produce auxin.

Auxin other than that added artificially is found in fruits that have been produced by treating the flower by phenylacetic acid.

The probable rôle of auxin in the growth of parthenocarpic and non-parthenocarpic fruit is discussed.

\footnotetext{
DEPARTMENT OF BOTANY,

Uyiversity of Micuigay Ann Arnor, Micitigan
}

\section{LITERATURE CITED}

Dorrfus, H. 1936. Wuchsstoffstudien. Planta 25: 1-21. Gardoner, F. E., and P. C. Martit. 1937. Parthenocarpic fruits induced by spraying with growth-promoting compounds. Bot. Gaz. 99 : 184-195.

Gustarson, F. G. 1936. Inducement of fruit development by growth-promoting chemicals. Proc. Nat. Acad. Sci. 22: 628-636.

. 1937. Parthenocarpy induced by pollen extracts. Amer. Jour. Bot. 24: 102-107.
. 1938a. Further studies on artificial parthenocarpy. Amer. Jour. Bot, 95 : $237-944$.

__. 1938b. Induced parthenocarpy. Bot. Gaz. 99: 840-844.

1939. The cause of natural parthenocarpy. Amer. Jour. Bot. $96: 135-138$.

Hagemans, P. 1937. Über durch B-indolessigsäure ausgeläste Parthenokarpie der Gladiole. Gartenbauwissenschaft. $11: 144-150$. 
Laibaci, F, 1932. Pollenhormon und Wuchsstoff. Ber. Deutsch. Bot. Ges. 50: 383-390.

Meyer, F. 1936. Über die Verteilung des Wuchsstoffes in der Pflanzen während ihrer Entwicklung. Dissertation. Johann Wolfgang Goethe Universität zur Frankfort am Mainz.

Thmass, K. V. 1934. Studies on the growth hormone of plants. VI. The distribution of the growth substance in plant tissues. Jour. Gen. Physiol. 18: 23-34.

VAx OverneE K, J. 1938. A simplified method for auxin extraction. Proc. Nat. Acad. Sci. 24: 42-46.
Went, F. W. 1938. Specific factors other than auxin affecting growth and root formation. Plant Physiol. $13: 55-80$.

, and K. Y. Thimane. 1937. Phytohormones. New York.

Yasuda, S., T. Inaba, and Y. Takahasmi. 1935. Parthenocarpy caused by the stimulation of pollination in some plants of the cucurbitaceae. (Japanese with English résumé.) Agriculture and Horticulture 10: 1385-1390.

\section{OBSERVATIONS ON THE GENUS PSEUDOLPIDIUM ${ }^{1}$}

\section{A. McLarty}

Following THE early observations of Nägeli (1846), several workers, including Cienkowski (1855), Braun (1855), and Pringsheim (1860), reported the presence of various bodies in swollen filaments of water molds; but little intense work was done on them until Cornu (1872) published the results of his studies. He recognized these bodies to be parasites and described several species, in three of which he observed spiny, thick walled resting spores with one or more smooth or slightly echinulated, thin-walled, empty cells attached to them. Cornu considered these spores to have arisen from a fusion of a smaller male thallus with a larger female one and interpreted the empty cells as the antheridia. Using this sexual spore character as the diagnostic feature, Cornu thus established the genus Olpidiopsis for these small, intramatrical parasites.

Later Fischer (1880), studying what he thought to be Cornu's type species $O$. Saprolegniae, failed to find resting spores with attached antheridial cells and came to doubt Cornu's earlier observations. In 1882 he rejected the "adjacent cell character" and restricted the genus Olpidiopsis to forms which possessed asexual resting spores. Subsequent studies, however, convinced Fischer that his earlier work was incorrect, and in 1892 he confirmed the observations of Cornu and reinstated the genus $\mathrm{Ol}$ pidiopsis to its original status. At the same time, he established the genus Pseudolpidium to include $\mathrm{Ol}$ pidiopsis-like species which produce resting spores without adjacent cells. Of the six species which Fischer recognized, only two are tenable, inasmuch as he did not observe the resting spores of four of them. In $P$. Saprolegniae he described smooth, flatspherical to ellipsoidal zoosporangia (fig. 5, 6) and spiny resting spores of similar size and shape (fig. $9)$. In $P$. fusiforme Fischer described smooth, long ellipsoidal to cylindrical zoosporangia associated with similar long, spiny resting spores (fig. 2).

Butler (1907), studying various other species of Pseudol pidium, has not supported Fischer with ref-

1 Received for publication January 14, 1939.

'The writer wishes to express appreciation and thanks to Prof. H. B. Berdan, of the University of Western Ontario, for the culture from which this study was made, and to Prof. J. S. Karling, under whose direction this investigation has been carried on, for his help and criticism. erence to this striking similarity between the zoosporangia and resting-spores but in all cases describes and figures spherical, definitely thick-walled, spiny resting spores which differ from the Olpidiopsis type of spore only in the absence of the adjacent cells.

In swollen filaments of Achlya secured in November, 1937, conspicuous, eylindrical, smooth sporangia (fig. 10) were observed together with long, spiny sporangia (fig. 11) as described by Fischer for $\dot{P}$. fusiforme. In the same culture smooth, ellipsoidal zoosporangia (fig. 14) were present as well as spiny sporangia of the same size and shape (fig. 15), which have been described by Fischer for $P$. Saprolegniae. Dependent apparently upon conditions of growth, zoosporangia were found to vary greatly in size and shape, and in any culture a complete series from spherical to cylindrical could be observed. Spiny sporangia showed similar variation in size and shape, and the degree of spininess was found to vary from slight echinulations to heavy bristles. These bristly bodies showed no tendency to rest but liberated zoospores readily, thereby proving themselves to be nothing more than zoosporangia which,

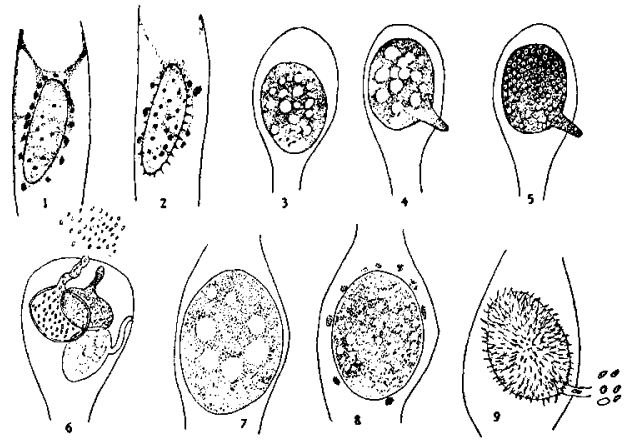

Fig. 1-9 were copied from plates given by Fischer and Pringsheim.-Fig. 1-2. Stages in the development of the resting-spore of Pseudolpidium fusiforme (127 $\times$, after Fischer).-Fig. 3-5. Stages in the development of the zoosporangium of Pseudolpidium Saprolegniae (127 $\times$, after Fischer).-Fig. 6. Zoosporangia of Pseudolpidium Saprolegniae (87 $\times$, after Pringsheim).-Fig. 7-9. Stages in the development of the resting-spore of Pseudolpidium Saprolegniae (117 $\times$, after Fischer). 